\title{
Platinum-group minerals and their host chromitites in Macedonian ophiolites
}

\author{
THIERRY AUGÉ ${ }^{1, *}$, GUILlaUme MORIN ${ }^{1}$, LAURENT BAILLY $^{1}$ and TODOR SERAFIMOVSKY ${ }^{2}$ \\ ${ }^{1}$ Bureau de Recherches Géologiques et Minières (BRGM), Mineral Resources Division, 3 avenue \\ Claude-Guillemin, BP 36009, 45060 Orléans Cedex 2, France \\ *Corresponding author, e-mail: t.auge@brgm.fr \\ ${ }^{2}$ University "Goce Delcev"-Stip, Faculty of Natural and Technical Sciences, Institute of Geology, \\ Goce Delcev 89, 2000 Stip, Macedonia
}

\begin{abstract}
Several ophiolite bodies that have been a significant source of chromium ore are located in the Vardar Zone of Macedonia. Three relatively small (maximum $15 \times 4 \mathrm{~km}$ ) bodies have been studied in detail. In the Radusa and Lojane complexes, the mantle series consisting of harzburgite and rare dunite are well preserved, whereas minor pyroxenite and gabbro occurrences belong to a poorly preserved cumulate series. The Rabrovo massif corresponds to the basal part of the cumulate sequence. In all three complexes, chromitite mineralization occurs as pods and irregular layered bodies and exhibits all the characteristics of typical ophiolite mineralization with nodular, orbicular, net, schlieren or massive texture, and an $\mathrm{Mg}-\mathrm{Cr}$-rich composition. Platinum-group minerals (PGM) are associated with the chromitite concentrations. Described for the first time in Macedonia, they are typical of ophiolitic chromitite, dominated by the laurite-erlichmanite solid solution, and rare Ru-Os-Ir alloy, cuprorhodsite and cuproiridsite. One of the characteristics of the Macedonian PGM is a relative $\mathrm{Cu}$ enrichment, marked by $\mathrm{Cu}-\mathrm{PGM}$, but also by the presence of $\mathrm{Cu}$ in solid solution in laurite, and the occurrence of a Cu-sulfide rim around the PGM trapped in chromite crystals, suggesting that $\mathrm{Cu}$ was present in the PGE-S system.
\end{abstract}

Key-words: platinum-group minerals (PGM); laurite; chromitite; ophiolite complex; Vardar Zone; Macedonia.

\section{Introduction}

Numerous peridotite-gabbro bodies, corresponding to dismembered ophiolite complexes, are known in Macedonia and in the Eastern Mediterranean region (Fig. 1). Most ophiolite bodies in Macedonia include chromite occurrences. The size of these chromite deposits is widely variable; estimated resources range from a few hundred tons up to 1.5 million $t$, most commonly being between 1,000 and $20,000 \mathrm{t}$. The shape of the ore bodies is also variable, but they exhibit all the morphologies described for podiform ophiolite occurrences (pencil-shaped, lenses, pipe-like or irregular morphologies). They have been intensively mined, especially during the Second World War.

Platinum-group minerals (PGM) have been described in most ophiolitic chromitites around the world, but not in Macedonia, where the chromitites themselves and their host rocks remain poorly known. This paper reports, for the first time, PGM in three ophiolite occurrences in Macedonia, discusses their composition with reference to other PGM in similar contexts and the reason for the PGM/ chromite association with reference to various hypotheses published in the recent literature. The compositions of the host chromitites and their environment are also presented and discussed with reference to various models.

\section{Geological context}

The geology of Macedonia comprises several tectonic units, which extend into the northern and southern Balkans. The western part of Macedonia belongs to the Dinarides-Hellenides belt; the central part includes two units: the Pelagonides and the Vardar Zone (Bozovic et al., 2013). The Pelagonides are a moderate-to-high-grade metamorphic terrane of Precambrian rocks representing a thrust sheet from the distal part of the Adriatic passive margin. The Vardar Zone comprises the Western Vardar Ophiolitic Unit and the Eastern Vardar Ophiolitic Unit (Schmid et al., 2008). The highly dismembered ophiolites in the Vardar Zone are related to a back-arc basin (Pamic et al., 2002) formed by spreading during the initial stages of intra-oceanic subduction (Robertson, 2002). Among the ophiolite occurrences in Macedonia, three poorly documented complexes were studied and sampled (Fig. 1).

\subsection{The Radusa massif}

This massif has been the most important source of chromite of the history of the former Yugoslavia with around 1.5 Mt of ore mined between 1890 and 1945 from open pits and underground workings. The ultramafic 


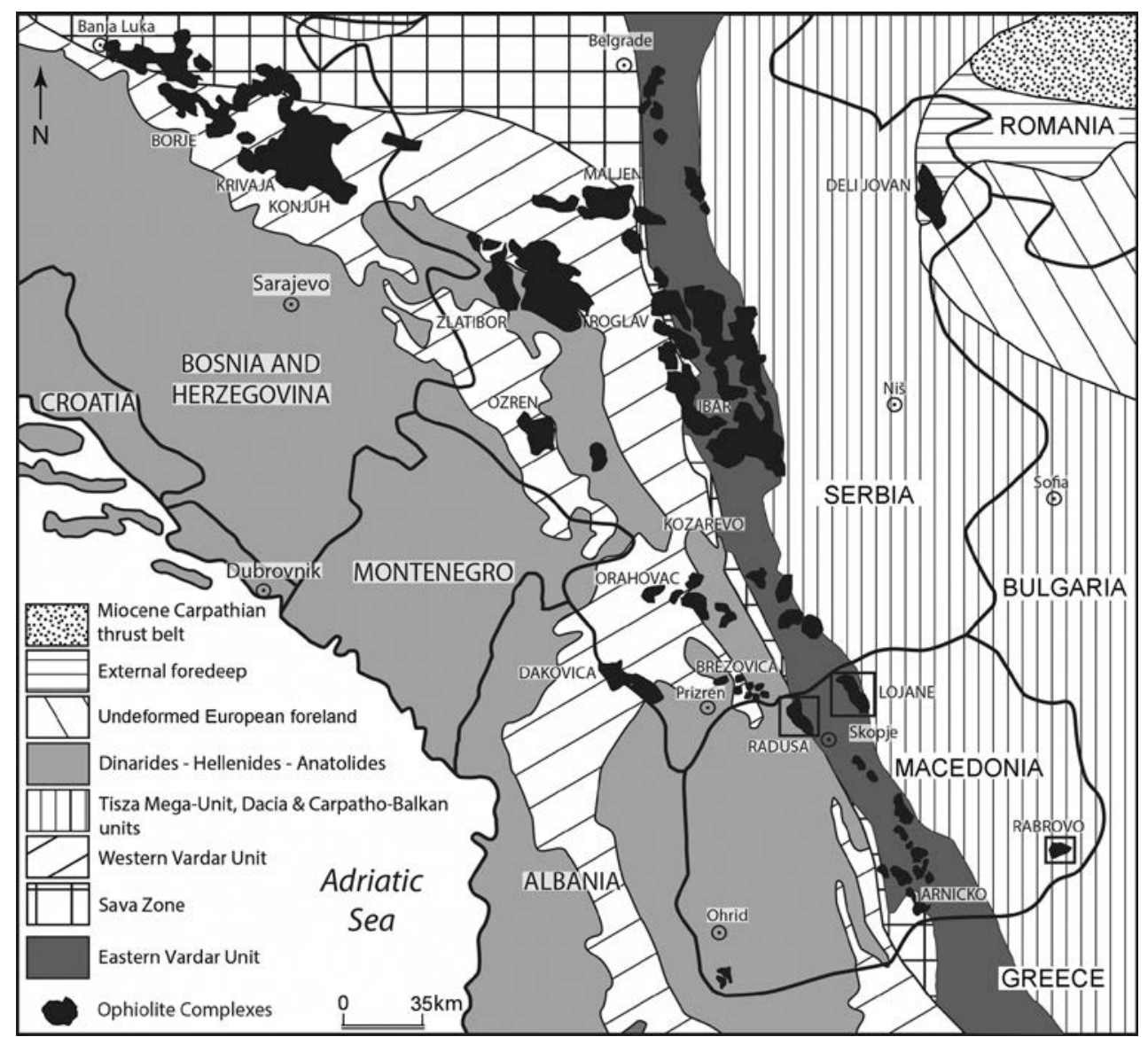

Fig. 1. Simplified geological map of the Eastern Mediterranean showing the principal ophiolite occurrences (after Bozovic et al., 2013). Square: position of the three ophiolites studied in Macedonia.

massif is located on the western flank of the Eastern Vardar Unit (Fig. 1), emplaced onto Triassic schists and limestones and overlain by Cretaceous sediments (Fig. S1, after Jankovic, 1986, freely available online as Supplementary Material linked to this article on the GSW website of the journal, http://eurjmin.geoscienceworld.org/). The estimated thickness of the massif is $2.5 \mathrm{~km}$; it is about $17 \mathrm{~km}$ long and $4 \mathrm{~km}$ wide. A summary of the geology of the complex is given by Jankovic (1986).

The massif corresponds to the mantle sequence of ophiolite stratigraphy, consisting of harzburgite and minor dunite, and dykes of pyroxenite and gabbro that are especially abundant in the northeastern part of the complex close to the basal cumulate series. Three hundred chromitite occurrences are scattered within the massif; of these, eleven were of major importance. The chromite texture is typical of ophiolite complex, e.g. nodular, orbicular, net texture, schlieren or massive ore.

Chromite occurrences seem to be irregularly distributed within the harzburgite sequence. This mantle sequence exhibits a "basal zone", dominated by dunite, where chromite occurs as massive ore in pipe-shaped and podiform bodies. The largest and richest deposits $(0.1$ to $1.2 \mathrm{Mt}$ ) are located in this basal zone. A "middle zone" is dominated by harzburgite with minor dunite bodies and rare chromite occurrences; an "upper zone" completes the mantle series. The latter is composed of dunite with lenses of harzburgite and dykes of pyroxenite and gabbro with chromite bodies taking the form of lenses sub-parallel to the foliation of the host rock. A "mixed series" terminates the succession and has been interpreted as the basal cumulate series with dunite, pyroxenite and gabbros.

Fourteen samples of the Radusa complex were collected, mainly around the Vitina Padina and Caska ore bodies (Fig. S1a). The former ore body has been mined underground $(100,000 \mathrm{t}$ of ore excavated,) and three chromitite samples were collected from the main adit plus three of ultramafic rocks. For the latter, chromite veins and lenses (showing vertical layering, with average thickness $80 \mathrm{~cm}$ ) were sampled in the open pit (seven chromitites and one peridotite).

\subsection{The Lojane massif}

The Lojane ophiolite complex is located in the Eastern Vardar zone. It is $11 \mathrm{~km}$ long and 1 to $4 \mathrm{~km}$ wide and consists of three units: (1) a basal mantle sequence with harzburgite and minor dunite and "fragmented bodies" and veins of pyroxenite, overlain by (2) the cumulate sequence with basal dunite, followed by lherzolite, pyroxenite and gabbro; the uppermost volcano-sedimentary sequence (3) is thought to belong to the complex (Fig. S1b, after Jankovic, 1986, available online). 
The distinctive feature of this complex is that it has been intruded by numerous small tertiary granite bodies and dacitic andesite. An $\mathrm{Sb}-\mathrm{As}$ sulfide mineralization located in silicified serpentinites and locally in chromitite is associated with the dacitic andesite.

Chromite mineralization occurs (1) as small bodies (irregular pods or pencil-like occurrences) in the deepest part of the harzburgite series and (2) at the transition zone between the mantle and the cumulate series; it takes the form of lenses and layers sub-parallel to the foliation. Ten major chromite deposits have been recognized, and the total chromite production from the Lojane complex is estimated at 200,000 t. Seventeen samples from five chromite occurrences (fourteen chromitites and three host rocks) were collected at the entrances to abandoned adits.

It should be noted that occurrences of "micron size grains of platinoids" are mentioned in chromitite from Lojane (Grafenauer, 1975, in Jankovic, 1986). This seems to be the first description of PGM in ophiolitic chromitite. This information seems to have passed unnoticed: it was only five years later that the first detailed description of PGM in ophiolitic chromitite was published internationally (Constantinides et al., 1980).

\subsection{The Rabrovo massif}

The Rabrovo massif corresponds to the northern extension of the Chalkidiki ophiolite belt. It is a small peridotite massif (about $0.25 \mathrm{~km}^{2}$, Fig. S1c, after Jankovic, 1986, available online). The body is strongly serpentinized and tectonically deformed, partly by a granite intrusion. It is mainly composed of wehrlite, with minor dunite as lenses and layers, and rare pyroxenite and gabbro.

Chromitite bodies occur in two main zones, in dunite and in wehrlite. Some small lenses are interpreted as a tectonically dismembered primary layer originally $150 \mathrm{~m}$ long and up to $4 \mathrm{~m}$ wide. The total $\mathrm{Cr}$ ore production is estimated at 150,000t. The description of the Rabrovo ophiolite (in Jankovic, 1986) suggests that in contrast with the two others described above, the mantle series is lacking, the whole massif corresponding to the basal cumulate sequence. Owing to difficult outcrop conditions, three ultramafic rocks were collected around the old working and two chromitite samples were collected from dumps at the abandoned mines.

\section{Analytical techniques}

Polished thin sections and polished sections were studied using a Leica DM4500P microscope in transmitted and reflected light. Chromite and silicates from selected chromitites and ultramafic rocks were analyzed using a CAMECA SXFive electron probe microanalyzer (EPMA) equipped with five wavelength-dispersive spectrometers under routine conditions. For each mineral, several analytical points were examined, and no zoning or significant variations were observed. Accordingly, average values are plotted on the compositional diagrams. All values given below are above the detection limit.
Chromitites were systematically examined under the microscope in reflected light, and all grains with high reflectivity were checked with an energy-dispersive spectrometer (EDS)-equipped HIROX SH-3000 scanning electron microscope (SEM). Qualitative analyses were thus obtained, enabling the PGM to be identified, and SEM images of each PGM were made, in some cases revealing complex PGM assemblages. The PGM were then analyzed using the SXFive EPMA under the following conditions: acceleration voltage $20 \mathrm{kV}$, a 20 -nA beam current and 10 -s counting time. The standards were pure metals, and $\mathrm{FeS}_{2}$ for $\mathrm{Fe}$ and $\mathrm{S}, \mathrm{Cr}_{2} \mathrm{O}_{3}$ for $\mathrm{Cr}$, AsGa for As. The $K \alpha$ lines were used for $\mathrm{Ni}, \mathrm{Cu}, \mathrm{Co}, \mathrm{Cr}, \mathrm{S}, K \beta$ lines for $\mathrm{Fe}, L \alpha$ lines for $\mathrm{Ir}$, $\mathrm{Ru}, \mathrm{Rh}, \mathrm{Pt}$ and $L \beta$ lines for $\mathrm{Pd}, \mathrm{As}$ and Os. Interferences due to peak overlap were resolved by using an overlap correction process (CamecaPeakSight software). The calculated detection limit (in $\mathrm{wt} \%$ ) varies from one analysis to another, but is around $0.5 \%$ for $\mathrm{Pt}, 0.3 \%$ for $\mathrm{Pd}$, $0.1 \%$ for $\mathrm{Rh}, 0.1 \%$ for $\mathrm{Ru}, 0.4 \%$ for Ir and $1.3 \%$ for Os. In most cases, the very small size of the grains analyzed explains the low totals obtained for most analyses. Chromium and $\mathrm{Fe}$ appear in all the compositions; these elements reflect excitation of the matrix. Hence, $\mathrm{Cr}$ and a proportion of $\mathrm{Fe}$ determined from knowledge of the $\mathrm{Cr} / \mathrm{Fe}$ ratio of the host chromite were subtracted from the raw analytical data, and the composition was recalculated to $100 \%$. Because of the good approximation to stoichiometry, this procedure is considered acceptable.

\section{Sample description and petrography}

\subsection{Ultramafic rocks}

The dominant facies described in the literature on the Radusa and Lojane ophiolite bodies are harzburgites with minor dunite. Most of the peridotites collected appear strongly serpentinized. Pyroxenites (websterite), displaying a generally porphyroclastic texture, were also collected. They appear much less altered. Accordingly, from Radusa, we collected three websterites and a serpentinized dunite, from Lojane two clinopyroxenites and a serpentinized harzburgite and from Rabrovo a serpentinized dunite and a websterite.

Figure $2 \mathrm{a}$ and $\mathrm{b}$ shows various types of texture for different facies. Broadly speaking, the websterites are strongly deformed, with features typical of mantle deformation, a texture generally observed in harzburgite (and rarely in dykes). None of the pyroxenites exhibits a layered texture or relics of a cumulate texture.

\subsection{Chromitite}

Chromitite generally occurs in discontinuous layers, the chromite proportion ranging from 20 to $80 \%$. The silicate matrix is composed of serpentine (with in rare cases relics of olivine). Some samples show local deformation occurring as centimeter-sized bands of mylonite, and frequently large undeformed, subhedral chromite crystals occur in a "matrix" of cataclased fine-grained chromite 

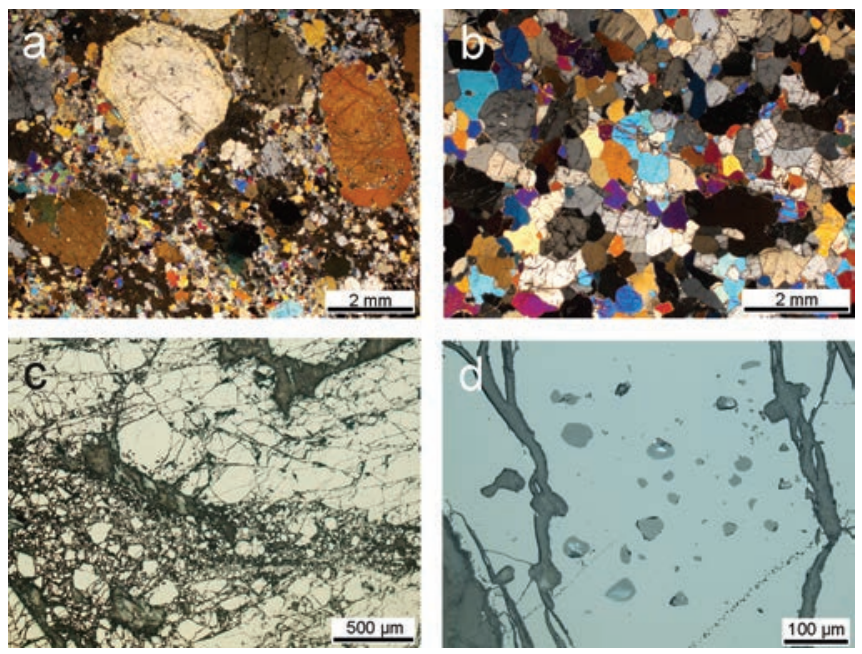

Fig. 2. Textures of selected rocks (a) porphyroblastic websterite, sample 57-5, Radusa Complex, Vitina Padina locality. (b) Pyroxenite, sample Ra1, adcumulate texture, Rabrovo Complex. (c) Submassive chromitite showing mylonite bands, sample 57-2 Radusa Complex, Vitina Padina ore body. (d) Cluster of silicate inclusions in a chromite crystal. Sample 41-5, Lojane chromitite. (a and b) cross-polarized transmitted light, (c and d) plane-polarized reflected light. Scale bar: (a), (b) $2 \mathrm{~mm}$, (c) $0.5 \mathrm{~mm}$, (d) $0.1 \mathrm{~mm}$. (Online version in color.)

crystals (Fig. 2c). Commonly, some of the chromite crystals contain silicate inclusions (olivine, pyroxene, or amphibole, which are either isolated or form "clusters", Fig. 2d).

For Radusa, we analyzed chromitites from the two orebodies sampled, and for Lojane, four out of the five occurrences sampled. For Rabrovo, one sample was analyzed. In terms of characteristics and texture we did not find any difference between the three massifs.

\section{Mineral composition}

Olivine has been found (1) in serpentinized harzburgite; its forsterite (Fo) content ranges between 90.63 and $92.80 \mathrm{~mol} \%$ and $\mathrm{NiO}$ between 0.24 and $0.45 \mathrm{wt} \%$; (2) in the chromitite matrix (Fo 93.13-93.79, NiO 0.39-0.55 wt $\%$; and (3) as inclusions in chromite crystals from chromitite (Fo 96.92-97.00\%, NiO 0.55-0.86 wt\%).

Orthopyroxene has been found in websterite from the Rabrovo and Radusa ophiolite; it is totally altered in harzburgite. In the Rabrovo pyroxenite, its Mg-number $(100 \mathrm{MgO} /(\mathrm{MgO}+\mathrm{FeO})$ in mol\%) ranges between 84.83 and 85.58 whereas for Radusa, it is generally lower and ranges between 66.55 and $84.86 \%$. In both settings, its $\mathrm{Cr}_{2} \mathrm{O}_{3}$ content is low $(0.05$ to $0.30 \mathrm{wt} \%$, Table 1$)$ and the correlation between $\mathrm{Cr}$ and the $\mathrm{Mg}$-number (Fig. 3) is compatible with a differentiation trend.

Like orthopyroxene, clinopyroxene has been found in pyroxenite (clinopyroxenite and websterite) and as inclusions in chromite crystals from chromitite. Clinopyroxene from Radusa is characterized by large variations in the Mg-number, from 96.11 to 74.51 , correlated with a drop in its $\mathrm{Cr}_{2} \mathrm{O}_{3}$ content (from 1.39 to $0.18 \mathrm{wt} \%$; Fig. 4a,
Table 1). Lojane and Rabrovo clinopyroxene crystals fall on the same correlation line. To a lesser extent, the drop in the $\mathrm{Mg}$-number is accompanied by an increase in $\mathrm{Al}_{2} \mathrm{O}_{3}$ (Fig. 4b). Clinopyroxene included in chromite crystals has a high Mg-number (94-95\%), and a high $\mathrm{Cr}_{2} \mathrm{O}_{3}$ content $(1.8 \mathrm{wt} \%)$, with relatively low $\mathrm{Al}_{2} \mathrm{O}_{3}(1.1 \mathrm{wt} \%$, Table 1$)$. The high $\mathrm{Cr}$ content cannot be attributed to analytical interference from the host chromite, as indicated by the low Al content. To the contrary, their compositions correspond well to the general clinopyroxene trend.

In most samples, owing to the porphyroclastic texture two types of pyroxene can be distinguished: large porphyroclasts generally with a prominent cleavage (Fig. 2a), and a matrix of fine-grained recrystallized clinopyroxene, without cleavage. The compositions of both are always very similar. The ternary diagram of Fig. 5 shows the coexisting evolution of both pyroxenes with equilibrium between the two.

Apart from chromite ore (Table 2), disseminated chromite crystals have been identified in both pyroxenite and serpentinite (altered harzburgite). Figure $6 \mathrm{a}$ gives the chromite composition by facies in the $\mathrm{Fe}^{3+}-\mathrm{Cr}-\mathrm{Al}$ ternary diagram and Fig. $6 \mathrm{~b}$ by complex. All the chromitites clearly plot in a very restricted part of the diagram. A much larger compositional range is obtained for the pyroxenite (s.l.), for which two trends are observed, one characterized by a Crfor-Al substitution observable in the Lojane pyroxenite, and a second, marked by an $\mathrm{Fe}^{3+}$ enrichment at a fairly constant $\mathrm{Al}$ content for the Radusa pyroxenite. The characteristics of the chromite composition are also illustrated in Fig. 7a and $\mathrm{b}$ where the three rock types (chromitite, harzburgite and cumulates) plot in the classical ophiolite domain (Barnes \& Roeder, 2001). The differentiation trend is marked here by a Ti enrichment in disseminated chromite from the Radusa pyroxenite, whereas the Lojane pyroxenite remains in comparison much less evolved.

\section{Platinum-group minerals}

The PGM were sought in 22 chromitite samples and have been identified in 15 sections. In spite of the limited statistics, it seems that they are more common in Radusa ( 8 sections out of 9 examined containing PGM), the number of grains identified per section ranging from one to six. A total of 45 grains were identified. All grains are totally enclosed within chromite crystals; some have an attached silicate. Most are euhedral with morphologies compatible with the cubic system, with sizes ranging from $0.1 \mu \mathrm{m}$ (too small for EPMA analyses) to $10 \mu \mathrm{m}$. Backscattered electron (BSE) SEM images (Fig. 8) show either isolated grains or composite inclusions. The polyphase inclusions are composed of two different PGM, or of a PGM apparently surrounded by a $\mathrm{Cu}$-bearing mineral. Note that the grain in Fig. 8f, located near a fracture zone and not totally included in the chromite crystal, seems to show alteration features. Apart from one Ru-rich alloy, all the PGM are laurite grains, and laurite is systematically present in polyphase PGM inclusions. 
Table 1. Selected electron microprobe analyses of orthopyroxene and clinopyroxene. Web, websterite; Clinopx, clinopyroxenite; Chrom, chromitite.

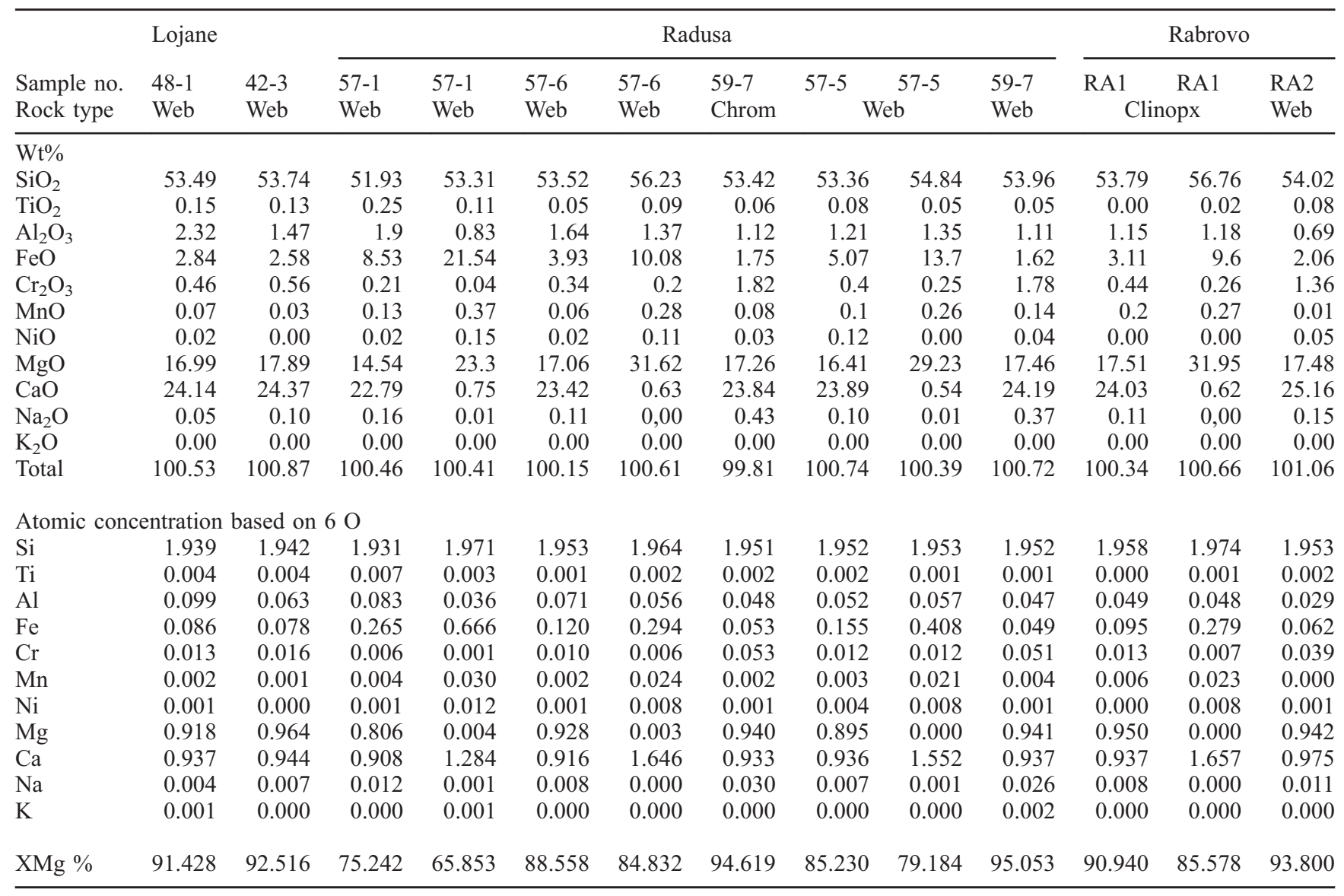

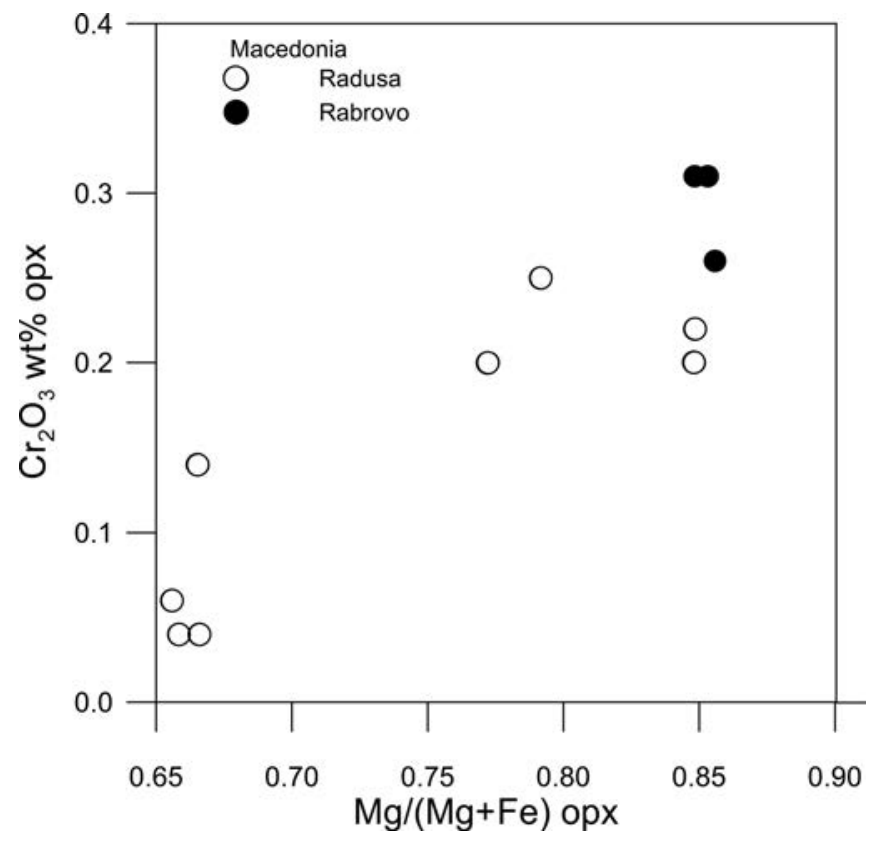

Fig. 3. Plot of $\mathrm{Cr}_{2} \mathrm{O}_{3}$ vs. $\mathrm{Mg} /\left(\mathrm{Mg}+\mathrm{Fe}^{2+}\right)$ in molar percent in orthopyroxene for the Radusa and Rabrovo pyroxenites. This illustrates the differentiation trends in the Rabrovo pyroxenite.

\subsection{Laurite}

Laurite composition differs from one grain to another within a single chromitite sample. Its grain size did not allow us to establish the existence of zoning, as described by González-Jiménez et al. (2009b). Considering the $\mathrm{Cr} / \mathrm{Fe}$ ratio of the laurite analysis, $\mathrm{Fe}$ has been removed. Arsenic and Co are generally below the detection limit. Copper seems to be invariably present, even in laurite apparently not associated with a $\mathrm{Cu}$-bearing mineral. Platinum ranges from below the detection limit to a maximum of $1.3 \mathrm{wt} \%$. Rhodium is also constantly present in laurite, between 0.15 and $4.04 \mathrm{wt} \%$ (Table 3). Laurite is characterized by a large Ru-for-Os substitution with a complete solid solution between the $\mathrm{RuS}_{2}$ (laurite) and $\mathrm{OsS}_{2}$ (erlichmanite) end-members. In $\mathrm{wt} \%, \mathrm{Ru}$ ranges between 11.0 and 53.6, Os between 2.6 and 56.4 (Fig. 9) and $\mathrm{Ir}$ between 3.6 and 9.6. Atomic concentrations are plotted in the triangular diagram of Fig. 10. The large variations in $\mathrm{Ru} / \mathrm{Os}$ in the sulfide do not appear to be specific to any particular environment.

Figure $8 \mathrm{~g}$ and $\mathrm{h}$ shows a laurite grain with a Cu-bearing aureole. The laurite in Fig. 8g does not exhibit significant $\mathrm{Cu}$ values, whereas the one in Fig. 8h bears (after correction) $7.8 \mathrm{wt} \% \quad \mathrm{Cu}$. The chemical analysis is 

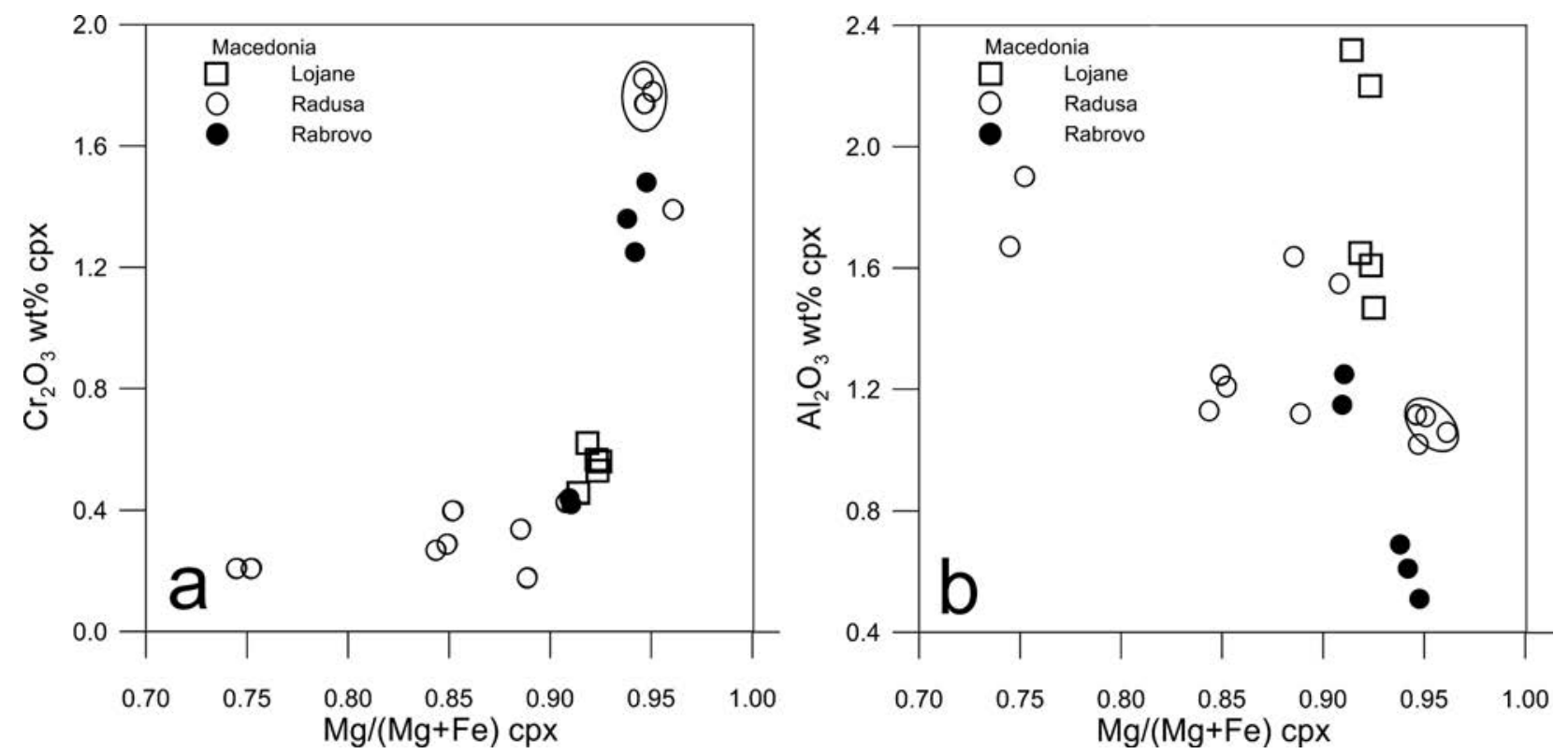

Fig. 4. Plots of (a) $\mathrm{Cr}_{2} \mathrm{O}_{3} v s . \mathrm{Mg} /\left(\mathrm{Mg}+\mathrm{Fe}^{2+}\right)$ in molar percent and (b) $\mathrm{Al}_{2} \mathrm{O}_{3} v s$. $\mathrm{Mg} /\left(\mathrm{Mg}+\mathrm{Fe}^{2+}\right)$ in molar percent in clinopyroxene for the Lojane, Radusa and Rabrovo pyroxenites. Minerals included in chromite are circled.

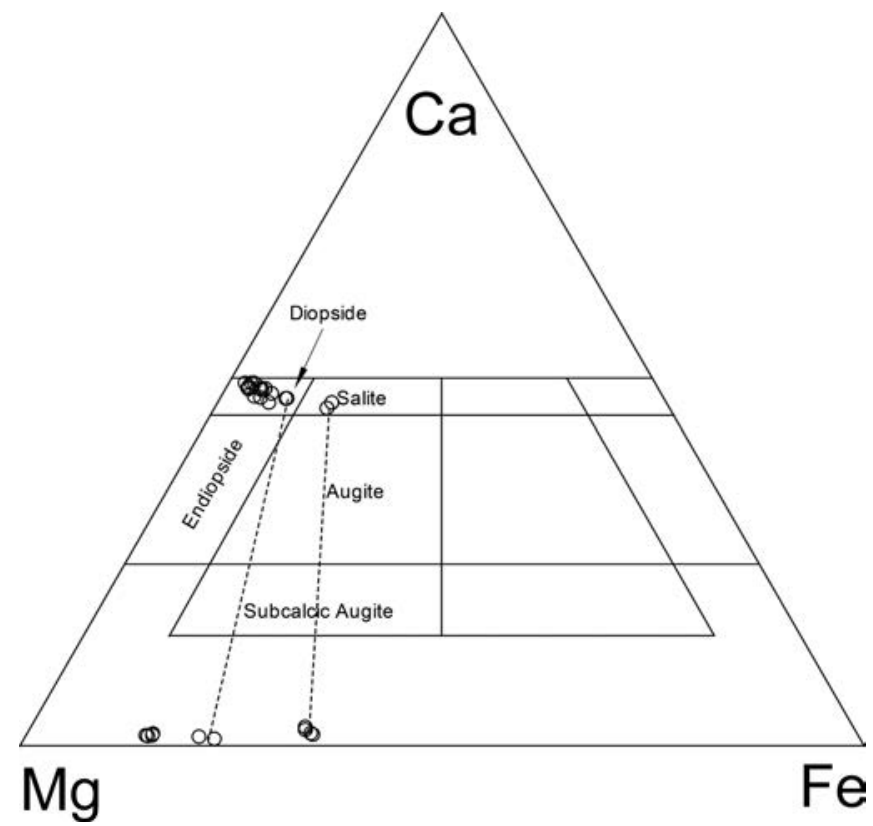

Fig. 5. Composition of ortho- and clinopyroxene in the pyroxene ternary diagram.

compatible with a structural formula assuming the substitution of $\mathrm{Cu}$ in laurite $\left(\mathrm{Ru}_{0.66} \mathrm{Cu}_{0.21} \mathrm{Os}_{0.09} \mathrm{Ir}_{0.04}\right) \mathrm{S}_{2}$ (Table 3). Garuti et al. (1999) described from the Othrys ophiolite complex a composite inclusion of cuproiridsite, laurite and an unspecified $\mathrm{Cu}$ sulfide "that appears to have crystallized later than the PGM".

\subsection{Alloy}

Only one PGE alloy was found; it occurs as a monophase inclusion in sample 59-1 (Radusa, Table 3). Its recalculated composition indicates (avg. of two analyses in wt\%)
$\mathrm{Ru}$ 63.8, Os 19.7, Ir 12.2 and Pt 0.6, Rh 1.2, Co 1.1 and $\mathrm{Cu}$ 0.14 . This composition is within the range of ruthenium compositions given by Cabri (2002). Note that the $\mathrm{Ru} / \mathrm{Os} /$ Ir atomic proportions correspond to those of the coexisting laurite (Fig. 10).

\subsection{Complex PGE sulfides}

Figure 8e shows a two-phase grain composed of laurite (Table 3, grain 44-1-b, point 32) and a complex Ir, Rh, Ru, $\mathrm{Cu}, \mathrm{Fe}$ sulfide. This composition (Table 3, point 27) with $55.20 \mathrm{wt} \% \mathrm{Ir}, 9.99 \mathrm{wt} \% \mathrm{Rh}$ and $6.21 \mathrm{wt} \% \mathrm{Cu}, 3.39 \mathrm{wt} \% \mathrm{Fe}$ and $25.11 \mathrm{wt} \% \mathrm{~S}$ resembles the cuproiridsite composition given by Cabri (2002). Note that considering the small size of the grain, analyses have been recalculated by removing the laurite contribution $(\mathrm{Ru}+\mathrm{Os}$ and the corresponding proportion of $\mathrm{S}$ ) and the proportion of $\mathrm{Fe}$ due to the host chromite. Atomic proportions calculated on the basis of the recalculated composition are $\left(\mathrm{Cu}_{0.516}\right.$, $\left.\mathrm{Fe}_{0.320}\right)_{0.836}\left(\operatorname{Ir}_{1.514}, \mathrm{Rh}_{0.512}\right)_{2.026} \mathrm{~S}_{4.134}$ which is not so far from the ideal formula of cuproiridsite. Indeed, this mineral is commonly reported in ophiolitic chromitites. A second cuproiridsite grain, associated with a laurite grain, was also detected in sample 59-2, both however being too small to be accurately analyzed.

A second mineral from the linnaeite group was discovered in sample 59-2, Radusa (Table 3, point 2); it appears adjacent to a very small laurite crystal. The $\mathrm{Cr} / \mathrm{Fe}$ ratio of the composition obtained suggests that $\mathrm{Fe}$ is present in the mineral composition. In the recalculated composition, we obtain (in wt $\%$ ) $\mathrm{Cu} 8.37, \mathrm{Fe} 4.39$, Rh 44.83, Ir 9.34, Pt 0.76, Pd 0.58 and S 31.66. The atomic proportion calculated on the basis of seven atoms per formula unit (apfu) is: $\left(\mathrm{Cu}_{0.545} \mathrm{Fe}_{0.325}\right)_{0.870}$ $\left(\mathrm{Rh}_{1.802} \mathrm{Ir}_{0.201} \mathrm{Pd}_{0.022}, \mathrm{Pt}_{0.016}\right)_{2.041} \mathrm{~S}_{4.083}$, which corresponds to cuprorhodsite. 
Table 2. Selected electron microprobe analyses of chromite. Web, websterite; Clinopx, clinopyroxenite; Chrom, chromitite; Harz, harzburgite; Srpn, serpentinite.

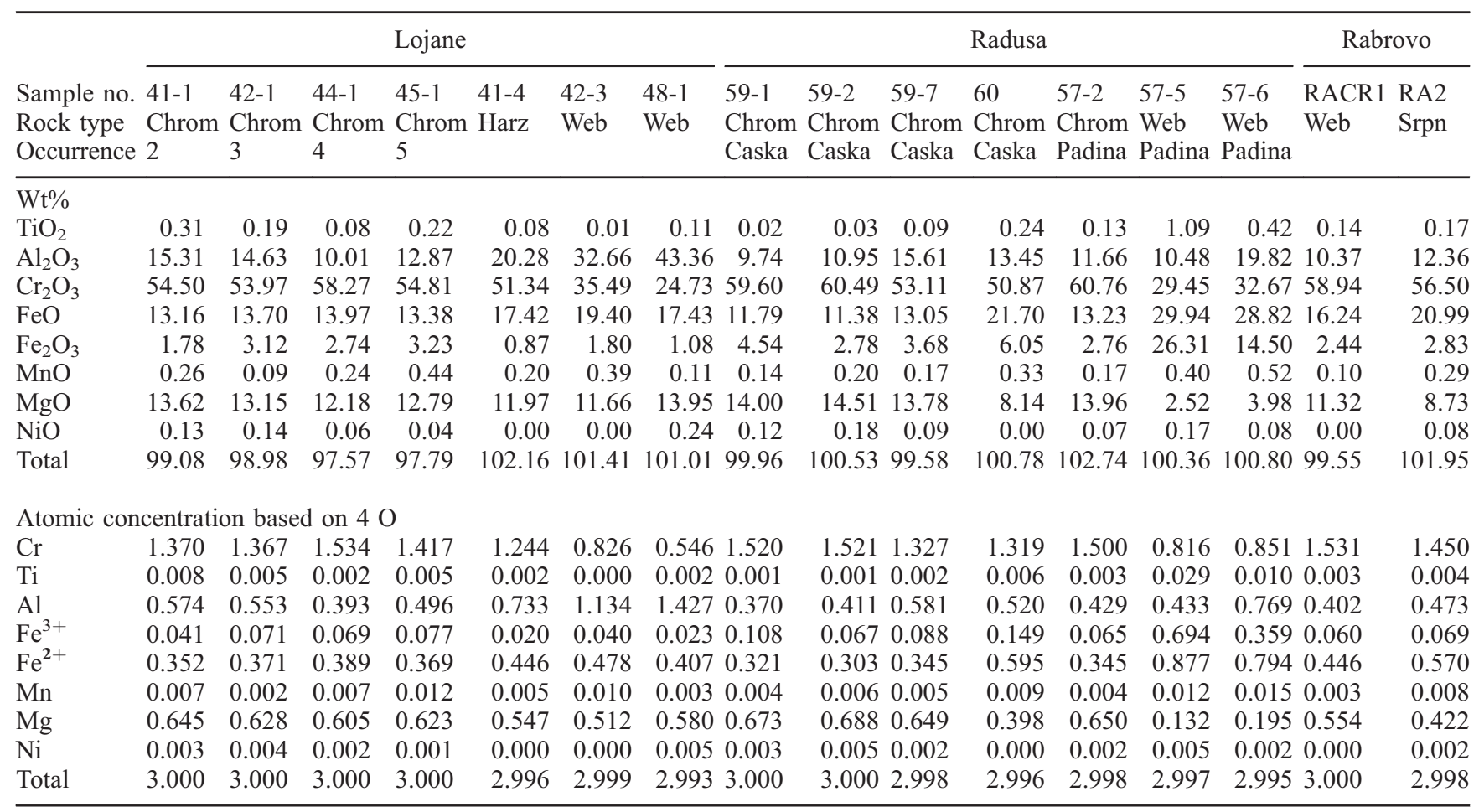
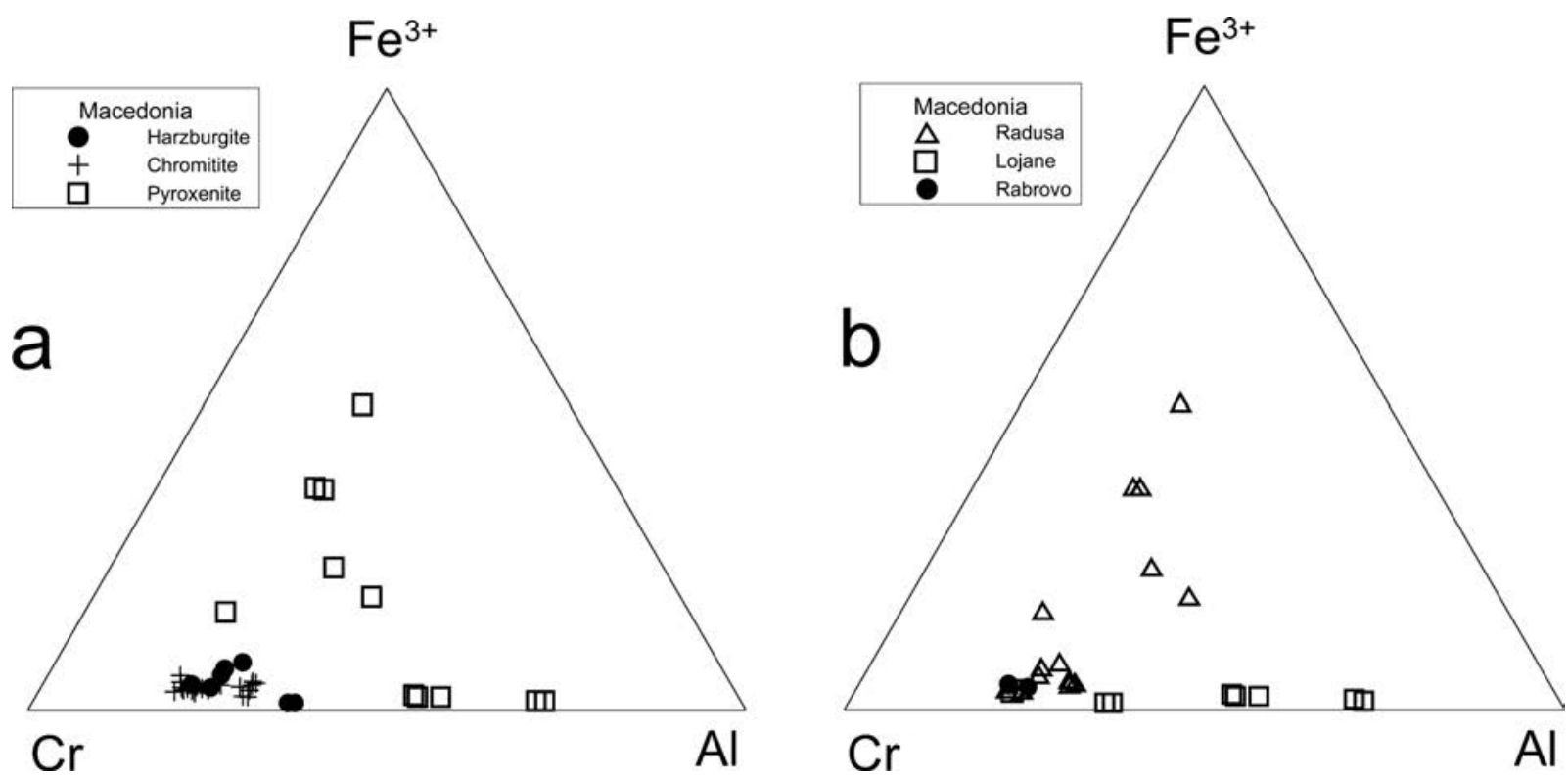

Fig. 6. Composition of chromite in the $\mathrm{Cr}-\mathrm{Al}-\mathrm{Fe}^{3+}$ ternary diagram (a) by rock type and (b) by geological complex.

\subsection{Cu-bearing rim}

Several laurite grains are surrounded by a $\mathrm{Cu}$-bearing rim (Fig. $8 \mathrm{~g}$ and $\mathrm{h}$ ) and are totally enclosed in chromite crystals. Thus, the development of the $\mathrm{Cu}$ rim must have occurred before the trapping of the assemblage in chromite. One rim (Fig. 8g) was large enough for EPMA analyses. After correction (removing minor amounts of Os and $\mathrm{Ru}$, and the corresponding portion of $\mathrm{S}$ due to laurite, and part of the Fe due to chromite), we obtain the following concentrations: $\mathrm{Cu} 73.69$, Fe 3.46, S 22.82 (in $\mathrm{wt} \%$ ) corresponding to the following atomic proportion: $\mathrm{Cu}_{0.600} \mathrm{Fe}_{0.030} \mathrm{~S}_{0.368}$ (Table 3, point 12). The possible minerals corresponding to this formula could be chalcocite $\mathrm{Cu}_{2} \mathrm{~S}$ or digenite $\mathrm{Cu}_{9} \mathrm{~S}_{5}$. Garuti et al. (1999) mentioned the occurrence of a $\mathrm{Cu}$ sulfide associated with a composite cuproiridsite-laurite association (filling the space between the PGM grains) but did not specify its composition. 

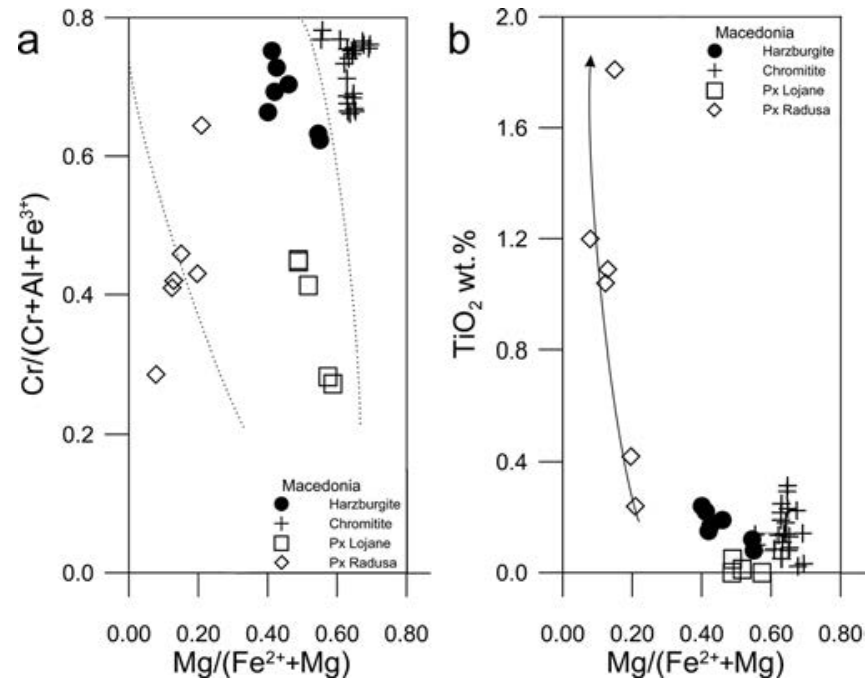

Fig. 7. Plots of (a) $\mathrm{Cr} /\left(\mathrm{Cr}+\mathrm{Al}+\mathrm{Fe}^{3+}\right) v s . \mathrm{Mg} /\left(\mathrm{Mg}+\mathrm{Fe}^{2+}\right)$, both in molar percent (ophiolite domain, chromitite excluded, after Barnes $\&$ Roeder, 2001) and (b) $\mathrm{wt}^{\%} \mathrm{TiO}_{2}$ vs. $\mathrm{Mg} /\left(\mathrm{Mg}+\mathrm{Fe}^{2+}\right)$ in molar percent in chromite for chromitite, harzburgite and pyroxenite (s.l.) in the Macedonian ophiolite. The arrow shows the differentiation trends in the Radusa pyroxenite.

\section{Discussion}

\subsection{Platinum-group minerals}

Since the initial discovery of PGM in ophiolite chromitite, many publications have been devoted to the description of PGM in ophiolites all over the word, with diverse ages of emplacement and geodynamic environments. In most cases, they are composed of Ru, Os, and Ir, and minerals of the laurite-erlichmanite series are the most common. González-Jiménez et al. (2009a) studied the distribution and mode of occurrence of PGM in chromitites of 23 ophiolite occurrences, exhibiting "podiform" or "stratiform" chromitite concentrations. They found that Os-, Ir-, and Ru-rich PGM are only slightly more abundant (52\%) than Pt-, Pd-, and Rh-rich PGM (48\%), but when only podiform chromitites are considered, the proportion of the former reaches $72 \%$, and $93 \%$ if one considers only primary PGM included in chromite crystals.

The origin of the PGM in ophiolitic chromitite has been widely debated. Gijbels et al. (1974) and Naldrett \& Cabri (1976) invoked the possibilities of incorporation of the PGE at high temperature, followed by exsolution on cooling. It is now accepted that the morphology of the PGM and their diversity is not compatible with the exsolution process. Constantinides et al. (1980) and Talkington et al. (1984) then suggested that the PGM were trapped during chromite growth.

Augé (1988) proposed that the PGM crystallized before, or contemporaneously with, chromite and then were trapped, PGM playing the role of a nucleus. The accumulation of chromite crystals to form pods or layers will play the role of a "mechanical" collector of the PGM formed in the magma, thereby explaining the relative enrichment of PGE in chromitite. This has been
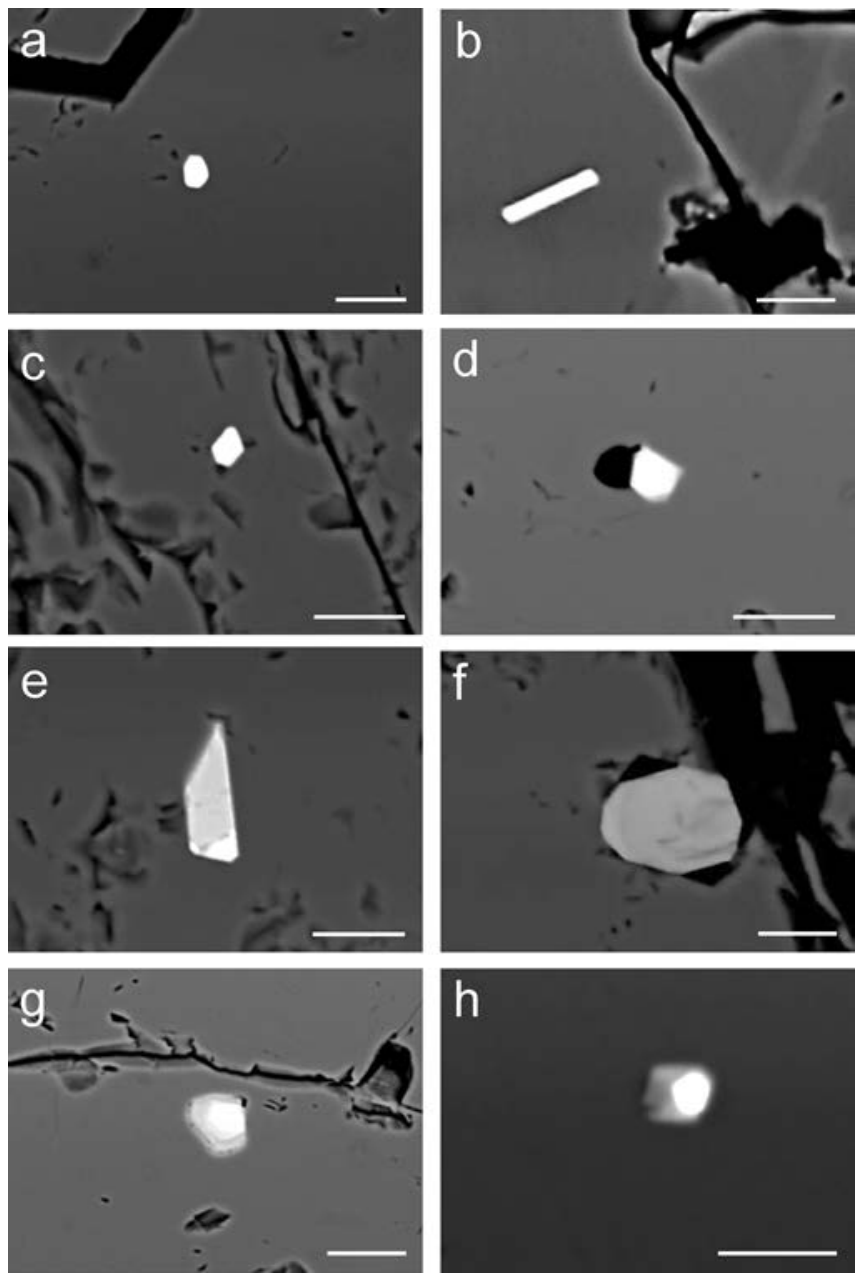

Fig. 8. Back-scattered electron images of PGM in chromite. (a) Euhedral laurite, sample 45-1, point 34 (Table 3). (b) Tabular laurite, sample 41-3. (c) Hexagon-shaped laurite, sample 42-1, point 21 (Table 3). (d) Euhedral laurite with an attached silicate (black), sample RaCr1b, point 14 (Table 3). (e) Polyphase inclusion, sample 44-1-b, with laurite (point 24, Table 3) - cuprorhodsite (point 27, Table 3). (f) Apparently altered laurite sample 41-1-b, point 32 (Table 3). (g) Laurite surrounded by a halo of an undetermined $\mathrm{Cu}$ sulfide. Sample RaCr1-a, point 10 (Table 3). (h) Laurite associated with an undetermined $\mathrm{Cu}$ mineral. Sample 44-1-c (point 29, Table 3). Scale bar is $10 \mu \mathrm{m}$.

demonstrated for the Tiébaghi massif (New Caledonia ophiolite) where PGM have also been found as inclusions in disseminated chromite from coexisting dunite, "precursory" to podiform chromitite.

All the PGM discovered in the Macedonian chromitites are enclosed in chromite crystals, and among the 45 grains discovered, 44 grains are laurite (41 single grains and 3 composite grains) and 1 is a ruthenium grain. The composite grains are composed of a laurite and a cuproiridsite ( 2 cases) or a laurite and a cuprorhodsite (1 case). According to González-Jiménez et al. (2009a), cuproiridsite represents $1 \%$ of the PGM included in unaltered podiform chromitite, whereas cuprorhodsite is not mentioned, Rh taking the form of hollingworthite (PtAsS). Except for the absence of PGM in fractures and silicate matrix, the distribution of PGM in podiform 


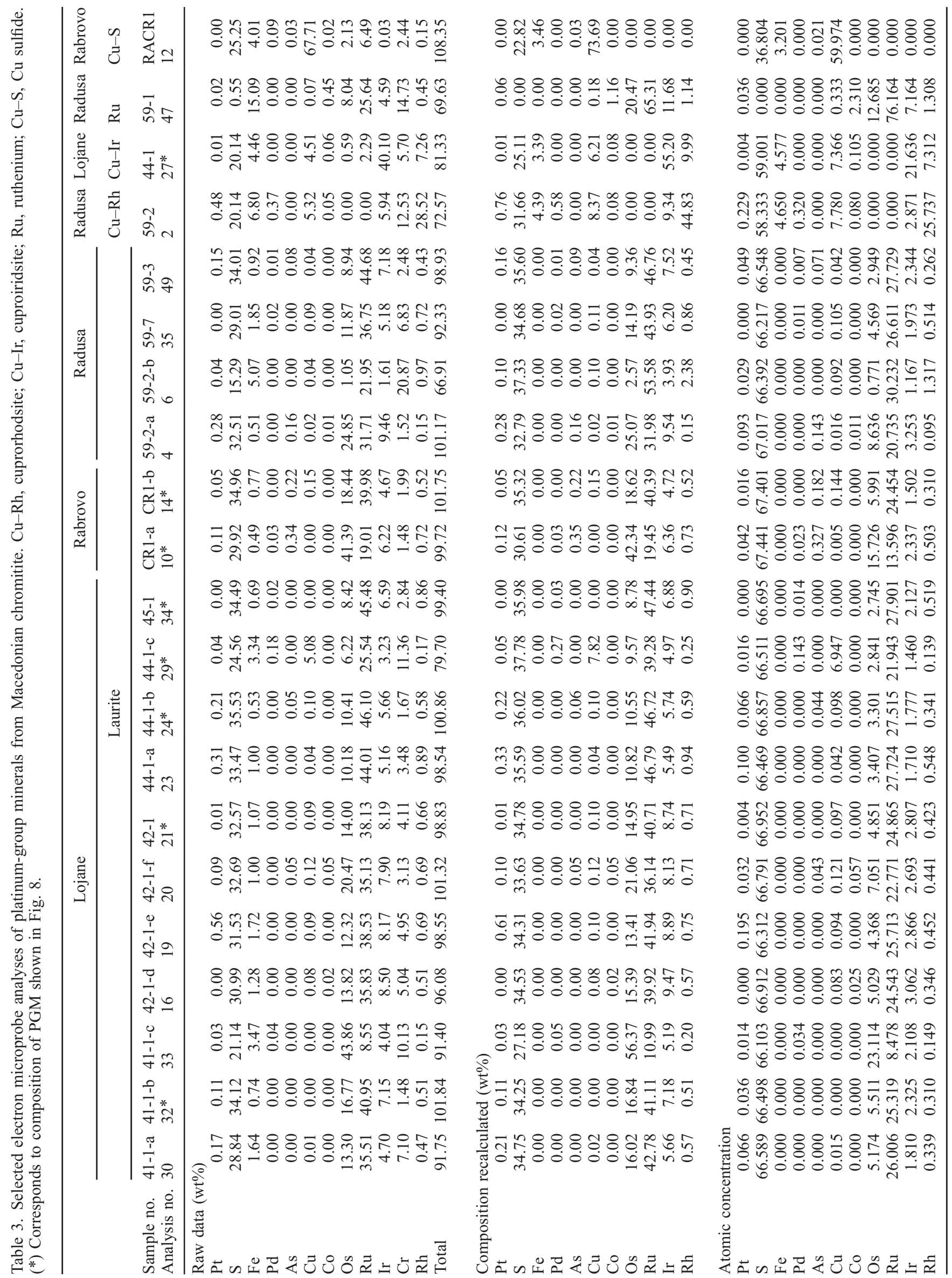




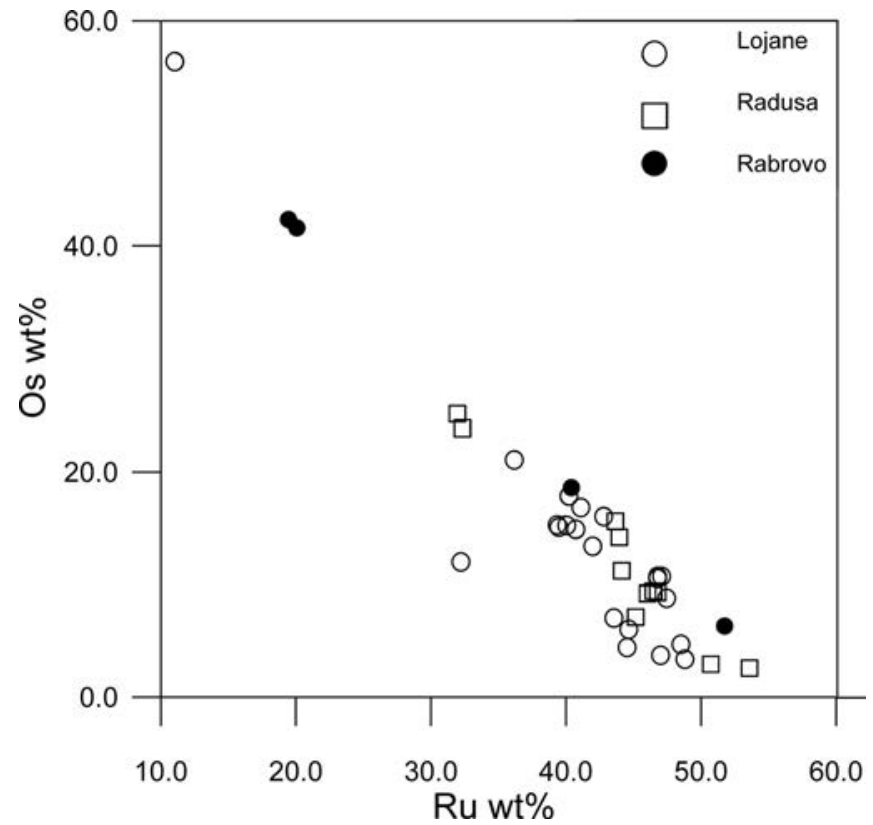

Fig. 9. Plot of Os $v s . \mathrm{Ru}$ in $\mathrm{wt} \%$ in laurite included in chromite from chromitite in the Lojane, Radusa and Rabrovo ophiolite complexes.

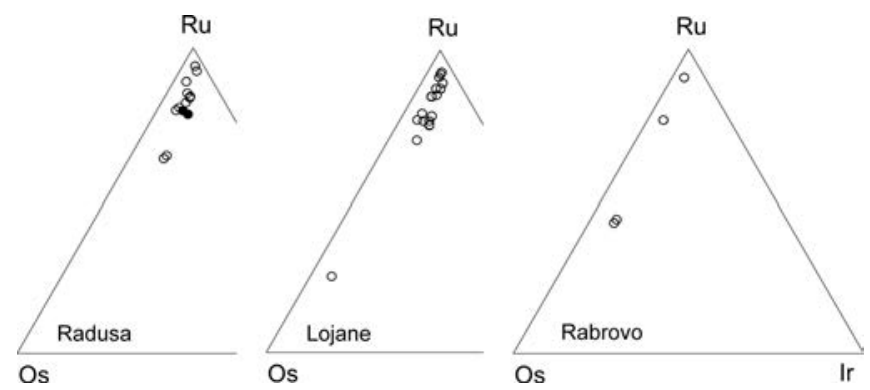

Fig. 10. Plots of Ru-Os sulfides (open circle) and alloy (black circle) in PGM included in chromite from chromitite in the Lojane, Radusa and Rabrovo ophiolite complexes.

ophiolite chromitite from Macedonia is in good agreement with the statistical distribution established by GonzálezJiménez et al. (2009a). The composition of the Macedonian laurite is in perfect agreement with literature data (Johan, 1986; Augé \& Johan, 1988; Garuti et al., 1999, compilation in Kapsiotis et al., 2009; González-Jiménez et al., 2009a). Similarly, Ru alloys together with Ir and Os are common in ophiolitic chromitites as is cuproiridsite. Cuprorhodsite seems to be much less common. The presence of $\mathrm{Cu}$ minerals associated with the PGM has also been described (Augé, 1988; Garuti et al., 1999). The $\mathrm{Cu}$ sulfides or $\mathrm{Cu}-\mathrm{Fe}$ sulfides, together with $\mathrm{Ni}$ sulfides or $\mathrm{Ni}-$ Fe sulfides very commonly, occur as inclusions in chromite crystals, with or without attached PGM. The $\mathrm{Cu}-\mathrm{S}$ aureole observed for the Radusa and Lojane samples suggests that $\mathrm{Cu}-\mathrm{S}$ crystallization followed the $\mathrm{Ru}-\mathrm{Os}-\mathrm{S}$ crystallization. Copper was present in the PGE-S system as indicated by presence of $\mathrm{Cu}$-bearing PGM and also the presence of significant amounts of $\mathrm{Cu}$ in solid solution in laurite (see Table 3, point 29).
Recent developments in the application of $\mathrm{Re}-\mathrm{Os}$ isotopic analysis to PGM-bearing chromitites, including direct Os isotope measurement on individual PGM grains (Malitch et al., 2003; Malitch, 2004; Ahmed et al., 2006; Shi et al., 2007; Marchesi et al., 2011; González-Jiménez et al., 2012a and b, 2013), bring new insight to our understanding of the origin of PGM in ophiolite chromitite. In a recent paper, GonzálezJiménez et al. (2014a) confirmed that in situ analysis of the Os isotopes in individual grains of PGM in ophiolitic chromitites reveals very heterogeneous compositions, even at the scale of single grains. They suggested that the genesis of PGM with heterogeneous Os-isotope compositions probably reflects the crystallization of chromite by the mixing/mingling of multiple batches of melts that have sampled different mantle sources. This mixing mechanism may produce "mixed" Os-isotope compositions even within single PGM. They proposed three mechanisms to explain the origins of PGM in ophiolitic chromitites. The first suggests that not all PGM now hosted in the ophiolitic chromitites were necessarily formed by direct precipitation from melts. Residual phases such as laurite or Os-Ir alloys could be produced by the breakdown of pre-existing PGE-bearing basemetal sulfides in the mantle. The PGM already present in the mantle could also be incorporated as a solid or a solid/ melt mush into the parental melts of chromitites. This hypothesis is still very speculative. The second suggests that the PGM were introduced into pre-existing chromite once they were formed. Chromitites may be transported deep into the mantle by subduction processes, and possibly incorporated into the convecting mantle. Again, this model needs to be constrained. They could be infiltrated and veined by metasomatic fluids/melts that would promote the precipitation of PGM. The third hypothesis involves the partial or complete destruction of the PGM, and their recrystallization, during polyphase metamorphism or recycling of the chromitites in the deeper mantle.

Whatever the mechanism involved, it remains true that the presence of PGM cannot be dissociated from the processes of chromitite formation, described as multiple injections of magma depositing chromite (of probably various origins, and containing - or not containing - PGM crystallized from various sources and levels in "mini" chambers to form pods and layers). Thus, the model developed some years ago by Lago et al. (1982) probably contains the basic mechanisms that have never since been questioned. This model is perfectly compatible with the various mechanisms suggested by González-Jiménez et al. (2014a and b) to explain the characteristics of the PGM and the associated chromitites and can easily be applied to the Macedonian examples. The contributions of "hydrous fluids" to the origin of chromite deposits, while often mentioned (Johan et al., 1982, 1983; Melcher et al., 1997), have never been fully accepted. 


\subsection{Chromitite}

With a high $\mathrm{Mg}$ number (around 0.6), a high $\mathrm{Cr}$ / $\mathrm{Cr}+\mathrm{Al}+\mathrm{Fe}^{3+}$ ratio, and very low $\mathrm{TiO}_{2}$ and $\mathrm{Fe}_{2} \mathrm{O}_{3}$ contents, the Macedonian chromitites are typical of podiform chromitite (Barnes \& Roeder, 2001). Moreover, there are very few variations from one occurrence to another and from one complex to another. With a high $\mathrm{Cr}$ content, their composition is very similar to that of chromitite from Greek ophiolites (Pindos, EconomouEliopoulos et al., 1999; Vourinos, Augé, 1988).

It is generally accepted that such a composition reflects crystallization from "boninitic melt in an island arc environment" (Akmaz et al., 2013), as opposed to a midoceanic ridge setting. With a specific enrichment in Os, Ir and $\mathrm{Ru}$ relative to $\mathrm{Rh}, \mathrm{Pt}$ and $\mathrm{Pd}$, it also corresponds to the Type I defined by González-Jiménez et al. (2014b).

\subsection{Ultramafic rocks}

The strong alteration undergone by harzburgite and dunite has totally obliterated their texture and chemistry. On the other hand, all the other facies sampled in the three complexes, pyroxenite (with in some cases minor olivine, totally serpentinized), websterite (more common) and clinopyroxenite appear well preserved. Two types of texture are represented: a typical adcumulate magmatic texture (Fig. 2b) and a porphyroclastic texture (Fig. 2a). In most cases, this latter texture is the result of mantle deformation. In this context, pyroxenite occurs either as dykes (which are rather common in the upper part of mantle series) or cumulates. Adcumulate textures are relatively undeformed and can be found either in dykes in the mantle series or in the cumulate sequence. The porphyroblastic texture has completely obliterated the magmatic texture of the pyroxenites, but their relatively high proportion within the complexes suggests that they correspond to basal cumulates that have been affected by mantle deformation. In spite of their deformation, the mineral composition shows wide variations (more pronounced at Radusa) compatible with differentiation trends marked by a decrease in the $\mathrm{Mg}$ number in both pyroxenes, accompanied by a decrease in $\mathrm{Cr}_{2} \mathrm{O}_{3}$ and an increase in $\mathrm{Al}_{2} \mathrm{O}_{3}$. Similarly, in the Radusa disseminated spinel, we see a clear increase in $\mathrm{Fe}^{3+}$, with a similar increase in $\mathrm{TiO}_{2}$ at a low $\mathrm{Mg}$ number. At Lojane (only two samples), clinopyroxene seems less differentiated, and disseminated spinels have low $\mathrm{TiO}_{2}$, low $\mathrm{Fe}^{3+}$ and a high $\mathrm{Mg}$ number.

Obviously, Radusa, and to a lesser extent Rabrovo and Lojane, are examples of differentiated pyroxenite cumulates that have been affected by mantle deformation. It remains clear, however, that all the chromitites occurrences sampled are typical podiform mantle chromitite and do not belong to the cumulate evolution of the complexes.

\section{Conclusions}

Platinum-group minerals have been found as inclusions in chromitite from three ophiolite bodies in Macedonia. Their composition is typical for this type of context, dominated by the laurite-erlichmanite solid solution, with rare $\mathrm{Ru}-$ Os-Ir alloy, cuprorhodsite and cuproiridsite. One of the characteristics of the Macedonian PGM is a relative $\mathrm{Cu}$ enrichment, with $\mathrm{Cu}-\mathrm{PGM}$, but also, the presence of $\mathrm{Cu}$ in solid solution in laurite, and the occurrence of $\mathrm{Cu}$ sulfides rimming the PGM trapped in chromite crystals, suggests that $\mathrm{Cu}$ was present in the PGE-S system. Similarly, the host podiform chromitite exhibits textures and compositions typical of ophiolitic environments. Samples collected in the mantle sequence of the Lojane and Radusa bodies are strongly altered, except for some pyroxenite dykes. Basal cumulate pyroxenite displays an unusual porphyroblastic texture typical of mantle deformation. At the scale of the ophiolite body, the pyroxenites exhibit a differentiation trend compatible with a fractional crystallization process, confirming that they are deformed cumulates.

Acknowledgments: We thank Guillaume Wille for the EPMA analyses obtained with the CamecaSXFive at the "Plateforme analytique régionale" (BRGM - University - CNRS, Orléans), and Prof. Uysal and an anonymous reviewer for their critical comments. J.V. Guy-Bray edited the English text. We dedicate this work to the memory of Zdenek Johan, who taught us to share his passion for PGE mineralization.

\section{References}

Ahmed, A.H., Hanghøj, K., Kelemen, P.B., Hart, S.R., Arai, S. (2006): Osmium isotope systematics of the Proterozoic and Phanerozoic ophiolitic chromitites: in situ ion probe analysis of primary Os-rich PGM. Earth Planet. Sci. Lett., 245, 777-791.

Akmaz, R.M., Uysal, I., Saka, S. (2013): Petrogenesis of ophiolitic chromitites from Southeastern Turkey: chromite composition and geochemistry and mineralogy of platinum group elements. Geophys. Res. Abstr., 15, EGU 2013, 12859.

Augé, T. (1988): Platinum group minerals in the Tiébaghi and Vourinos ophiolitic complexes: genetic implications. Can. Mineral., 26, 177-192.

Augé, T. \& Johan, Z. (1988): Comparative study of chromite deposits from Troodos, Vourinos, North Oman and New Caledonia ophiolites. in "Mineral Deposits within the European Community", J. Boissonnas \& P. Omenetto, ed. Springer-Verlag Berlin Heidelberg, 267-288.

Barnes, S.J. \& Roeder, P.L. (2001): The range of spinel compositions in terrestrial mafic and ultramafic rocks. J. Petrol., 42, 2279-2302.

Bozovic, M., Prelevic, D., Romer, R.L., Barth, M, Van Den Bogaard, P., Boev, B. (2013): The Demir Kapija Ophiolite, Macedonia (FYROM): a Snapshot of Subduction Initiation within a Backarc. J. Petrol., 54, 1427-1453.

Cabri, L.J. (2002): The platinum-group minerals. in "The geology, geochemistry, mineralogy and mineral beneficiation of platinum-group elements", L. Cabri, ed. Metallurgy and Petroleum Special Volume 54, Canadian Institute of Mining, Ottawa, Canada, 13-129.

Constantinides, C.C., Kingston, G.A., Fishert, P.C. (1980): The occurrence of platinum-group minerals in the chromitites of the Kokkinorotsos chrome mine, Cyprus. in "Ophiolites", A. Panayiotou, ed. Proceed. Intern. Ophiolite Symp., Cyprus, Nicosai, 93-101. 
Economou-Eliopoulos, M., Tarkian, M., Sambanis, G. (1999): On the geochemistry of chromitites from the Pindos ophiolite complex, Greece. Chem. Erde, 59, 19-31.

Garuti, G., Zaccarini, F., Economou-Eliopoulos, M. (1999): Paragenesis and composition of laurite from chromitites of Othrys (Greece): implications for Os-Ru fractionation in ophiolitic upper mantle of the Balkan peninsula. Mineral. Deposita, 34, 312-319.

Gijbels, R.H., Millard, H.T., Desborough, G.A, Bartel, A.J. (1974): Osmium, ruthenium, iridium and uranium in silicates and chromite from the eastern Bushveld Complex, South Africa. Geochim. Cosmochim. Acta, 38, 319-337.

González-Jiménez, J.M., Gervilla, F., Proenza, J.A., Augé, T., Keterstedjian, T. (2009a): Distribution of platinum-group minerals in ophiolitic chromitites. Appl. Earth Sci., Trans. Inst. Mineral. Metall. B, 118, 101-110.

González-Jiménez, J.M., Gervilla, F., Proenza, J.A., Keterstedjian, T., Augé, T., Bailly, L. (2009b): Zoning of laurite $\left(\mathrm{RuS}_{2}\right)$ erlichmanite $\left(\mathrm{OsS}_{2}\right)$ : implications for the genesis of ophiolite chromitites. Eur. J. Mineral., 21, 419-432.

González-Jiménez, J.M., Gervilla, F., Griffin, W.L., Proenza, J.A., Augé, T., O'Reilly, S.Y., Pearson, N.J. (2012a): Os-isotope variability within sulfides from podiform chromitites. Chem. Geol., 291, 224-235.

González-Jiménez, J.M., Griffin, W.L., Gervilla, F., Kerestedjian, T.N., O’Reilly, S.Y., Proenza, J.A., Pearson, N.J., Sergeeva, I. (2012b): Metamorphism disturbs the Re-Os signatures of platinum-group minerals in ophiolite chromitites. Geology, $\mathbf{4 0}$, 659-662.

González-Jiménez, J.M., Marchesi, C., Griffin, W.L., GutiérrezNarbona, R., Lorand, J.-P., O'Reilly, S.Y., Garrido, C.J., Gervilla, F., Pearson, N.J., Hidas, K. (2013): Transfer of Os isotopic signatures from peridotite to chromitite in the subcontinental mantle: insights from in situ analysis of platinum-group and base-metal minerals (Ojén peridotite massif, southern Spain). Lithos, 164, 74-85.

González-Jiménez, J.M., Griffin, W.L., Gervilla, F., Proenza J.A., O'Reilly S.Y., Pearson, N.J. (2014a): Chromitites in ophiolites: How, where, when, why? Part I. A review and new ideas on the origin and significance of platinum-group minerals. Lithos, 189, 127-139.

González-Jiménez, J.M., Griffin, W.L., Proenza, J.A., Gervilla, F., O'Reilly, S.Y., Akbulut, M., Pearson, N.J., Arai, S. (2014b): Chromitites in ophiolites: how, where, when, why? Part II. The crystallization of chromitites. Lithos, 189, 140-158.

Grafenauer, S. (1975): Ore petrology of ultramafic associations in Yugoslavia. Acad. Sci., Cl. IV, 22, Ljubljana, 152 p. (In Serbian).

Jankovic, S. (1986): General feature of chromite deposits and major ore districts in Yugoslavia. in "Chromites", UNESCO's IGCP 197 Project: Metallogeny of ophiolites. Theophrastus Publications S.A., Athens, 67-89.

Johan, Z. (1986): Chromite deposits in the Massif du Sud ophiolite, New Caledonia: genetic consideration. in "Chromites", UNESCO's IGCP - 197 Project: Metallogeny of ophiolites. Theophrastus Publications S.A., Athens, 311-339.

Johan, Z., Robert, J.L., Volfinger, M. (1982): Role of reducing fluids in the origin of chromite deposits from ophiolitic complexes. Abstr., Geol. Assoc. Can., 7, 58.
Johan, Z., Dunlop, H., Le Bel, L., Robert, J.L., Volfinger, M. (1983): Origin of chromite deposits in ophiolitic complexes: evidence for a volatile- and sodium-rich reducing fluid phase. Fortschr. Mineral., 61, 105-107.

Kapsiotis, A., Grammatikopoulos, T.A., Tsikouras, B., Hatzipanagiotou, K. (2009): Chromian spinel composition and platinumgroup element mineralogy of chromitites from the Milia Area, Pindos ophiolite complex, Greece. Can. Mineral., 47, 10371056.

Lago, B., Rabinowicz, M., Nicolas A. (1982): Podiform chromite ore bodies: a genetic model. J. Petrol., 23, 103-125.

Malitch, K.N. (2004): Osmium isotope constraints on contrasting sources and prolonged melting in the Proterozoic upper mantle: evidence from ophiolitic Ru-Os sulfides and Ru-Os-Ir alloys. Chem. Geol., 208, 157-173.

Malitch, K.N., Junk, S.A., Thalhammer, O.A.R., Melcher, F., Knauf, V.V., Pernicka, E., Stumpfl, E.F. (2003): Laurite and ruarsite from podiform chromitites at Kraubath and Hochgrössen, Austria: new insights from osmium isotopes. Can. Mineral., 41, 331-352.

Marchesi, C., González-Jiménez, J.M., Gervilla, F., Garrido, C.J., Griffin, W.L., O’Reilly, S.Y., Proenza, J.A., Pearson, N.J. (2011): In situ Re-Os isotopic analysis of platinum-group minerals from the Mayarí-Cristal ophiolitic massif (MayaríBaracoa Ophiolitic Belt, eastern Cuba): implications for the origin of Os-isotope heterogeneities in podiform chromitites. Contrib. Mineral. Petrol., 161, 977-990.

Melcher, F., Grum, W., Simon, G., Thalhammer, T.V., Stumpfl, E.F. (1997): Petrogenesis of the ophiolitic giant chromite deposits of Kempirsai, Kazakhstan: a study of solid and fluid inclusions in chromite. J. Petrol., 38, 1419-1458.

Naldrett, A.J. \& Cabri L.J. (1976): Ultramafic and related mafic rocks: their classification and genesis with special reference to the concentration of nickel sulfides and platinum-group elements. Econ. Geol., 71, 1131-1158.

Pamic, J., Tomljenovic, B., Balen, D. (2002): Overview of the genesis and emplacement of Mesozoic ophiolites in the Eastern Mediterranean Tethyan region. Lithos, 65, 113-142.

Robertson, A.H.F. (2002): Overview of the genesis and emplacement of Mesozoic ophiolites in the Eastern Mediterranean Tethyan region. Lithos, 65, 1-67.

Schmid, S.F., Bernouilli, D., Fügenschuh, B., Matenco, L., Schefer, S., Schuster, R., Tischler, M., Ustaszewski, K. (2008): The Alpine-Carpathian-Dinaridic orogenic system: correlation and evolution of tectonic units. Swiss. J. Geosci., 101, 139-183.

Shi, R., Alard, O., Zhi, X., O'Reilly, S.Y., Pearson, N.J., Griffin, W.L., Zhang, M., Chen, X. (2007): Multiple events in the NeoTethyan oceanic upper mantle: evidence from Ru-Os-Ir alloys in the Luobusa and Dongqiao ophiolitic podiform chromitites, Tibet. Earth Planet. Sci. Lett., 261, 33-48.

Talkington, R.W., Watkinson, D.H., Wittaker, P.J., Jones, P.C. (1984): Platinum-group minerals and other solid inclusions in chromite of ophiolitic complexes: occurrence and petrological significance. Tschermaks Mineral. Petrogr. Mitt., 32, 285-301.

Received 1 September 2016

Modified version received 27 October 2016

Accepted 16 January 2017 